\title{
ANALISIS PENYEBARAN COVID-19 DENGAN MENGGUNAKAN MODEL SIR DAN VAKSINASI SERTA ESTIMASI PARAMETER
}

\section{Analysis of the Spread of Covid-19 Using SIR Models and Vaccination with Parameter Estimations}

\author{
Khozin Mu'tamar ${ }^{1 *}$, Supriadi Putra ${ }^{2}$, Sukma Adi Perdana ${ }^{3}$ \\ ${ }^{1,2}$ Program Studi Matematika, Jurusan Matematika, FMIPA, Universitas Riau \\ Kampus Bina Widya Km 12,5 Simpang Baru, Pekanbaru, 28293, Indonesia \\ ${ }^{3}$ Program Studi Managemen Pendidikan Islam STAIN Sultan Abdurrahman Kepulauan Riau \\ Jl.Ceruk Ijuk, Lintas Barat, Kab. Bintan, Kepulauan Riau, Indonesia
}

Corresponding author e-mail: ${ }^{1 *}$ khozin.mutamar@unri.ac.id

\begin{abstract}
Abstrak
Virus covid-19 merupakan virus baru yang berasal dari Wuhan yang hingga saat ini masih menyebar di seluruh di dunia, termasuk Indonesia. Vaksin virus yang masih dalam tahap awal penggunaan menyebabkan virus ini masih menyebar terus setiap waktunya. Penyebaran Covid-19 secara matematika dapat dianalisis menggunakan model epidemi dan kestabilan model dapat dilihat berdasarkan nilai bilangan reproduksi. Artikel ini membahas model SIR dan pemberian vaksinasi dengan menggunakan kontrol optimum untuk menganalisis penyebaran Covid-19. Bilangan reproduksi dasar ditentukan dengan menggunakan nilai parameter model yang kemudian diestimasi dengan menggunakan beberapa fungsi yang keduanya memanfaatkan data harian dan metode kuadrat terkecil. Hasil simulasi yang menggunakan data harian di wilayah Pekanbaru menunjukkan bahwa penggunaan fungsi polinomial lebih baik untuk menghampiri pola sebaran data reproduksi harian jika dibandingkan fungsi trigonometri dan eksponensial. Didapatkan juga bahwa vaksinasi dapat menekan penambahan populasi terinfeksi dan sangat bergantung pada tingkat efektivitas vaksinasi.
\end{abstract}

Kata Kunci : Covid-19, bilangan reproduksi dasar, model epidemi SIR, estimasi parameter, metode kuadrat terkecil.

\begin{abstract}
Covid-19 virus is a new virus originating from Wuhan which is still spreading throughout the world, including Indonesia. The vaccines for the virus are still in their early stages causing the virus to continue to spread all the time. The spread of the Covid-19 can be analysed mathematically using an epidemic model and the stability of the model can be seen based on the reproduction number. This article discusses the SIR model and vaccination using optimum control to analyse the spread of the Covid-19 virus. The reproduction number is determined using the parameter's model then estimated using several functions, both of them utilize by daily data and the least-squares method. The simulation results using daily data in the Pekanbaru show that the polynomial function is better for approaching the distribution pattern of daily reproduction numbers than the trigonometric and exponential functions. Moreover, it is also shown that vaccination can reduce the increase in the infected population and is very dependent on the effectiveness of vaccination.
\end{abstract}

Keywords: Covid-19, reproduction number, epidemic model SIR, parameter estimation, least square.

Article info:

Submitted: 02 ${ }^{\text {nd }}$ February $2021 \quad$ Accepted: $01^{\text {st }}$ May 2021

How to cite this article:

K. Mu'tamar, S. Putra, and S. A. Perdana, "ANALISIS PENYEBARAN COVID-19 DENGAN MENGGUNAKAN MODEL SIR DAN VAKSINASI SERTA ESTIMASI PARAMETER”, BAREKENG: J. Il. Mat. \& Ter., vol. 15, no. 2, pp. 323-334, Jun. 2021.

This work is licensed under a Creative Commons Attribution-ShareAlike 4.0 International License. Copyright @ 2021 Khozin Mu'tamar, Supriadi Putra, Sukma Adi Perdana 


\section{PENDAHULUAN}

Pada bulan Desember 2019, kasus pertama dengan gejala pneumonia ditemukan di Wuhan, Cina. Pada awal diagnosis, pneumonia tersebut diakibatkan oleh virus berjenis corona dan dinamakan dengan 2019-ncov [1]. Pada tanggal 10 Januari 2020, virus corona tersebut telah resmi diberi nama Covid-19 oleh Badan Kesehatan Dunia (WHO) [1] dan telah menjangkiti hampir seluruh wilayah di dunia. Covid-19 berkembang dan menyebar dengan cepat ke seluruh wilayah sehingga memaksa beberapa negara memberlakukan penutupan wilayah. Hingga 15 April 2020, sudah lebih dari dua juta kasus Covid-19 dilaporkan dari 210 negara yang mengakibatkan 120 ribu kematian. Berbagai upaya dilakukan untuk mencegah penyebaran virus diantaranya pembatasan sosial, karantina wilayah, pemberlakuan jam malam, penundaan dan pembatalan acara, serta penutupan beberapa fasilitas umum. Upaya ini termasuk karantina Hubei, karantina nasional di Italia dan di tempat lain di Eropa, serta pemberlakuan jam malam di Tiongkok dan Korea Selatan. Kasus pertama yang dilaporkan di Indonesia, secara resmi diumumkan pada tanggal 2 Maret 2020 dengan penderita adalah dua orang warga Jakarta [2]. Hingga akhir tahun 2020, penyebaran Covid-19 telah merata di 34 provinsi di Indonesia dengan total kasus positif terkonfirmasi mencapai $516.753[3]$.

Masifnya penyebaran Covid-19 mendorong banyak penelitian terkait model penyebarannya. Analisis penyebaran virus penyakit dalam matematika dapat dilakukan dengan menggunakan model Susceptible, Infected dan Removed (SIR) seperti pada [4]-[9] maupun sejenisnya yang telah dimodifikasi, seperti model SIR dengan intervensi pada [10] dan model SEIR pada [5] dan [6]. Beberapa model yang lebih kompleks dibahas oleh [1] yang melibatkan adanya karantina dan kematian serta pada [13] yang menambahkan proses penyembuhan pada model. Pada [14] dibahas tentang model SEIR dengan melibatkan adanya intervensi pada populasi yang terjangkit virus dan estimasi sebagian parameternya dilakukan dengan menggunakan algoritma PSO. Wang dkk. [5] telah mendeskripsikan beberapa model dasar terkait sebaran Covid-19 dan melakukan investigasi awal dengan menggunakan data beberapa negara. Juga dibahas tentang bagaimana intervensi dapat dilakukan untuk mengurangi laju penyebaran seperti penerapan isolasi, jaga jarak dan tindakan preventif lainnya. Malavikaa dkk. [6] menggunakan model SIR untuk menganalisis penyebaran infeksi Covid-19 di India dan menganalisis kenaikan jumlah kumulatif individu infeksi dengan menggunakan fungsi pertumbuhan logistik. Perbandingan antara model SIR dan SEIR dengan menggunakan data Wuhan dilakukan oleh Roda dkk [8]. Lebih jauh berdasarkan hasil penelitian Roda dkk [8], dinyatakan bahwa estimasi dengan menggunakan model yang kompleks tidak selalu menghasilkan hampiran yang baik dibandingkan model yang lebih sederhana. Hal senada juga diberikan pada [7] yang menyatakan bahwa model SIR masih menjadi model yang cocok untuk estimasi karena karakteristik data yang tersedia. Hal ini membuat model SIR masih cukup layak untuk digunakan sebagai model untuk menganalisis penyebaran virus Covid-19.

Pada artikel ini dibahas model penyebaran Covid-19 dengan menggunakan model SIR dan kontrol berupa vaksinasi. Perkembangan Covid-19 ditinjau dengan bilangan reproduksi yang nilainya diestimasi dengan metode kuadrat terkecil dengan menggunakan data kasus harian wilayah Pekanbaru. Hasil estimasi data bilangan reproduksi kemudian dihampiri dengan empat fungsi estimasi, yaitu fungsi polinomial, eksponensial, trigonometri dan gabungan ketiganya. Selanjutnya, bentuk vaksinasi diterapkan pada model dengan menggunakan kontrol optimal sebagai metode kontrolnya. Artikel ini disusun dengan sistematika berikut. Setelah bagian ini diberikan metodologi yang berisi langkah kerja pengolahan data, estimasi parameter, dan desain kontrol. Bagian berikutnya dibahas tentang bilangan reproduksi model SIR dan estimasi parameter bagi fungsi bilangan reproduksi. Selanjutnya adalah desain kontrol optimum sebagai bentuk vaksinasi bagi model dan dilakukan simulasi berdasarkan data parameter menggunakan data kasus harian. Bagian terakhir ditutup dengan kesimpulan yang didapatkan dalam artikel ini.

\section{METODE PENELITIAN}

Secara garis besar, penelitian ini dilakukan berdasarkan diagram pada Gambar 1 yang dapat dijelaskan sebagai berikut

1. Formulasi model. Pada tahap ini dimodelkan penyebaran Covid-19 dengan menggunakan model epidemi SIR. Pemilihan model ini dikarenakan ketersediaan data yang lengkap jika dibandingkan model lainnya.

2. Analisis kestabilan. Model dianalisis kestabilannya dengan menggunakan bilangan reproduksi dasar $R_{0}$. 
3. Penentuan parameter model. Model yang dibentuk pada langkah pertama mengandung parameter model. Nilai ini ditentukan menggunakan metode kuadrat terkecil berdasarkan data lapangan. Untuk keperluan ini, digunakan data harian perkembangan Covid-19 di wilayah Pekanbaru provinsi Riau untuk kurun waktu September 2020 - Oktober 2020.

4. Perhitungan nilai $R_{0}$ dari model. Nilai $R_{0}$ diperoleh dengan menggunakan rumusan yang diperoleh pada langkah kedua dan parameter pada langkah ketiga. Nilai $R_{0}$ yang ditentukan adalah $R_{0}$ model dan $R_{0}$ harian. $R_{0}$ model diperoleh dengan menggunakan parameter yang diperoleh dari seluruh data lapangan yang digunakan. Sedangkan $R_{0}$ harian diperoleh berdasarkan parameter langkah ketiga yang dihitung pada interval data harian.

5. Penentuan fungsi kurva $R_{0}$. Nilai $R_{0}$ harian diestimasi dengan menggunakan sebuah fungsi. Pertama, nilai $R_{0}$ divisualisasi untuk ditebak fungsi yang mendekati pola datanya. Untuk keperluan ini, dipilih tiga fungsi yaitu fungsi polinomial berderajat $n$, fungsi trigonometri, eksponensial dan gabungan ketiga fungsi tersebut.

6. Desain fungsi vaksinasi. Tujuan vaksinasi adalah mengurangi laju sukses infeksi dari individu yang terinfeksi terhadap individu yang sehat. Untuk desain ini digunakan teori kontrol optimum dengan memanfaatkan Prinsip Minimum Pontryagin.

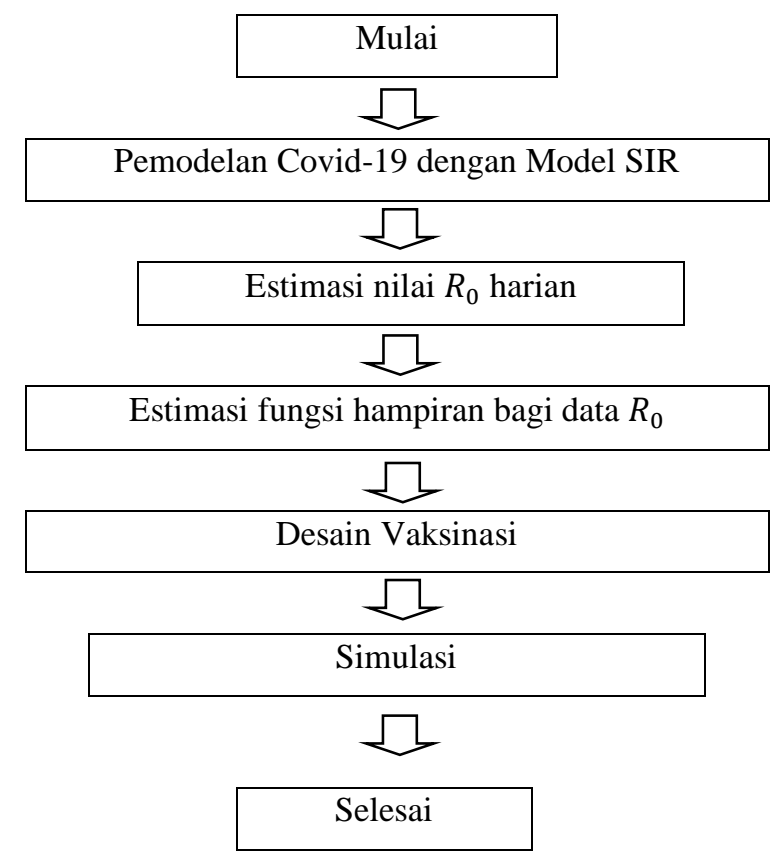

Gambar 1. Diagram proses penelitian

\section{HASIL DAN PEMBAHASAN}

\section{a. Model dan Kestabilan Epidemi Covid-19 dengan Menggunakan Model SIR}

Populasi sehat, terinfeksi dan sembuh berkumpul dalam satu area. Area diasumsikan dalam status tertutup sehingga tidak ada populasi masuk dan keluar dari area tersebut. Orang sehat dapat terpapar virus akibat interaksi dengan populasi terinfeksi. Pada skenario ini, populasi terinfeksi dikarantina namun populasi ini pernah berinteraksi dengan populasi sehat dan dampak yang ditimbulkan adalah populasi sehat langsung menjadi populasi sakit. Setiap populasi yang terpapar ataupun yang sakit memiliki kemampuan untuk penyembuhan diri. Penyembuhan yang sifatnya pengobatan diasumsikan seragam dengan penyembuhan diri serta diasumsikan kebal terhadap infeksi sehingga tidak terjadi infeksi lanjutan [15]. Model matematika yang digunakan dalam proses pemodelan adalah model SIR, yang merupakan akronim dari Susceptible (S), Infected (I) dan Removed (R). Penggunaan istilah Removed pada artikel ini dikarenakan populasi in terdiri atas individu yang sembuh (Recovered) dan Meninggal (Death). Model yang dibentuk berupa sistem persamaan diferensial biasa nonlinear. Proses pemodelan didasarkan pada alur penyebaran infeksi yang ditunjukkan pada Gambar 2. 


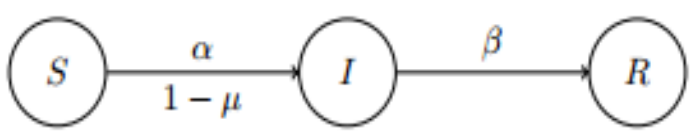

Gambar 2. Skema SIR untuk perubahan status populasi dalam penyebaran Covid-19

Variabel dan parameter yang terlibat pada model diberikan pada Tabel 1.

Tabel 1. Variabel dan parameter yang digunakan dalam pemodelan

\begin{tabular}{ll}
\hline Simbol & Definisi \\
\hline$S(t)$ & Populasi Susceptible, populasi sehat yang rentan terkena virus. \\
\hline$I(t)$ & $\begin{array}{l}\text { Populasi Infected, populasi yang telah dikonfirmasi terinfeksi virus } \\
\text { dengan menggunakan tes swab yang diuji melalui PCR }\end{array}$ \\
\hline$R(t)$ & $\begin{array}{l}\text { Populasi Removed, populasi yang telah bebas dari virus, bisa diartikan } \\
\text { sembuh maupun meninggal }\end{array}$ \\
\hline$\alpha$ & Laju sukses infeksi dari populasi Infected pada populasi Susceptible \\
\hline$\beta$ & Proporsi kesembuhan (kematian) populasi Infected \\
\hline$\mu$ & Indeks efektivitas kontrol vaksinasi yang diberikan \\
\hline
\end{tabular}

Berdasarkan skema Gambar 2 dan asumsi yang digunakan, maka model matematika SIR yang digunakan untuk menggambarkan penyebaran infeksi Covid-19 adalah

$$
\left\{\begin{array}{l}
\frac{d S(t)}{d t}=-\alpha(1-\mu) S(t) \frac{I(t)}{N} \\
\frac{d I(t)}{d t}=\alpha(1-\mu) S(t) \frac{I(t)}{N}-\beta I(t) \\
\frac{d R(t)}{d t}=\beta I(t)
\end{array}\right.
$$

dengan jumlah populasi setiap waktunya adalah $N=S(t)+I(t)+R(t)$. Oleh karena populasi total tiap waktu bersifat konstan, model dapat ditransformasi menjadi model tanpa dimensi. Didefinisikan $s(t)=\frac{S(t)}{N}, i(t)=\frac{I(t)}{N}$ dan $r(t)=\frac{R(t)}{N}$. Model tanpa dimensi dari penyebaran Covid-19 diberikan oleh

$$
\left\{\begin{aligned}
\frac{d s(t)}{d t} & =-\alpha(1-\mu) s(t) i(t) \\
\frac{d i(t)}{d t} & =\alpha(1-\mu) s(t) i(t)-\beta i(t) \\
\frac{d r(t)}{d t} & =\beta i(t)
\end{aligned}\right.
$$

Bilangan reproduksi merupakan angka yang menyatakan kemampuan suatu penyakit untuk berkembang sehingga ditetapkan $\frac{d i(t)}{d t}>0$ pada sistem (2) tanpa kontrol yaitu $\mu=0$. Agar individu terinfeksi mampu menyebarkan infeksi, karena $i(t) \neq 0$, dengan populasi awal $s(t) \approx 1$ maka bilangan reproduksi dasar dari model SIR (2) dinyatakan dengan

$$
R_{0}=\frac{\alpha}{\beta}
$$

Penyakit akan menyebar jika $R_{0}>1$.

\section{b. Estimasi $R_{0}$ Model SIR Covid-19 dengan Menggunakan Metode Kuadrat Terkecil}

Data yang tersedia masih mungkin bias untuk model SIR karena adanya migrasi penduduk yang menyalahi sifat tertutup pada model SIR. Untuk itu, digunakan metode kuadrat terkecil yang menggunakan Levenberg-Marquard untuk meningkatkan akurasi seperti pada [16] dan [17]. Penggunaan metode kuadrat 
terkecil banyak digunakan pada model epidemic seperti pada [16]-[19]. Misalkan $\phi(t, \mathbf{x})$ adalah solusi dari sistem persamaan diferensial biasa SIR pada persamaan (2). Diberikan data lapangan $D=\left\{\left(t_{j}, s_{j}, i_{j}, r_{j}\right) \mid t, s, i, r \geq 0, j=1,2,3, \ldots, n\right\}$. Jumlah kuadrat selisih antara solusi model SIR dan data lapangan adalah

$$
r(\mathbf{a})=\sum_{j=1}^{n}\left(d_{j}-\phi\left(t_{j}\right)\right)^{2}, \quad d \in D
$$

dengan $\mathbf{a}=\langle\alpha, \beta\rangle$ adalah parameter yang terdapat pada model SIR. Metode kuadrat terkecil dilakukan dengan menentukan nilai a sehingga nilai persamaan (4) minimum. Nilai a yang meminimumkan persamaan (4) diperoleh saat

$$
\frac{\partial r(\mathbf{a})}{\partial \mathbf{a}}=0
$$

Persamaan (5) merupakan sistem persamaan taklinier yang dapat ditentukan solusinya secara numerik dengan menggunakan metode Newton ataupun Levenberg-Marquard.

Data Covid-19 diklasifikasi dengan pengaturan pasien sembuh dan meninggal sebagai $R(t)$ dan pasien positif sebagai $I(t)$. Diasumsikan jumlah populasi awal adalah jumlah populasi Pekanbaru yang diambil berdasarkan data tahun 2020 yaitu $S_{0}=954.373$ [20]. Data perkembangan harian Covid-19 diberikan pada Tabel 2.

\begin{tabular}{|c|c|c|c|c|c|c|c|}
\hline Tanggal & Positif & Sembuh & Meninggal & Tanggal & Positif & Sembuh & Meninggal \\
\hline $1 / 9$ & 38 & 4 & 1 & $3 / 10$ & 115 & 48 & 5 \\
\hline $2 / 9$ & 47 & 4 & 1 & $4 / 10$ & 114 & 123 & 4 \\
\hline $3 / 9$ & 41 & 8 & 0 & $5 / 10$ & 126 & 150 & 4 \\
\hline $4 / 9$ & 46 & 16 & 5 & $6 / 10$ & 69 & 80 & 3 \\
\hline $5 / 9$ & 69 & 63 & 0 & $7 / 10$ & 84 & 143 & 3 \\
\hline $6 / 9$ & 60 & 69 & 3 & $8 / 10$ & 166 & 58 & 2 \\
\hline $7 / 9$ & 72 & 17 & 1 & $9 / 10$ & 124 & 56 & 2 \\
\hline $8 / 9$ & 87 & 27 & 2 & $10 / 10$ & 117 & 33 & 2 \\
\hline $9 / 9$ & 51 & 25 & 0 & $11 / 10$ & 55 & 24 & 0 \\
\hline $13 / 9$ & 129 & 16 & 5 & $12 / 10$ & 122 & 32 & 1 \\
\hline $14 / 9$ & 81 & 9 & 2 & $13 / 10$ & 86 & 12 & 2 \\
\hline $15 / 9$ & 68 & 29 & 3 & $14 / 10$ & 182 & 42 & 4 \\
\hline $16 / 9$ & 94 & 7 & 2 & $15 / 10$ & 93 & 55 & 2 \\
\hline $17 / 9$ & 120 & 7 & 3 & $16 / 10$ & 112 & 37 & 2 \\
\hline $18 / 9$ & 128 & 190 & 2 & $17 / 10$ & 158 & 63 & 3 \\
\hline $19 / 9$ & 190 & 45 & 0 & $18 / 10$ & 150 & 36 & 2 \\
\hline $20 / 9$ & 119 & 77 & 2 & $19 / 10$ & 65 & 421 & 3 \\
\hline $21 / 9$ & 72 & 22 & 2 & $20 / 10$ & 97 & 451 & 1 \\
\hline $22 / 9$ & 152 & 69 & 0 & $21 / 10$ & 153 & 176 & 8 \\
\hline $23 / 9$ & 113 & 38 & 8 & $22 / 10$ & 170 & 115 & 3 \\
\hline $24 / 9$ & 127 & 36 & 5 & $23 / 10$ & 97 & 182 & 2 \\
\hline $25 / 9$ & 122 & 82 & 4 & $24 / 10$ & 215 & 173 & 6 \\
\hline $26 / 9$ & 125 & 110 & 2 & $25 / 10$ & 121 & 383 & 1 \\
\hline $27 / 9$ & 92 & 116 & 3 & $26 / 10$ & 68 & 142 & 2 \\
\hline $28 / 9$ & 152 & 54 & 3 & $27 / 10$ & 112 & 169 & 5 \\
\hline $29 / 9$ & 109 & 84 & 4 & $28 / 10$ & 124 & 131 & 4 \\
\hline $30 / 9$ & 227 & 202 & 5 & $29 / 10$ & 111 & 121 & 5 \\
\hline $1 / 10$ & 158 & 133 & 4 & $30 / 10$ & 71 & 122 & 6 \\
\hline $2 / 10$ & 89 & 22 & 3 & $31 / 10$ & 37 & 105 & 2 \\
\hline
\end{tabular}

Tabel 2. Data harian kasus Covid-19 di Wilayah Pekanbaru periode bulan September-Oktober 2020

Sumber data: Dinas Kesehatan Riau

Berdasarkan Tabel 2, diperoleh banyak data $n=58$. Dengan menggunakan model SIR pada persamaan (2), terdapat dua parameter yang perlu ditentukan, yaitu $\alpha, \beta$. Sistem persamaan taklinier yang perlu diselesaikan adalah 


$$
\left\{\frac{\partial r(\alpha, \beta)}{\partial \alpha}=0, \frac{\partial r(\alpha, \beta)}{\partial \beta}=0\right\}
$$

Menggunakan data Tabel 2, nilai parameter $(\alpha, \beta)$ solusi dari persamaan (6) menggunakan modul leastsquare pada Python menghasilkan

$$
\{\alpha=0.0702671, \beta=0.04804334\}
$$

dengan error kuadrat $1.31382 e-6$ sedangkan sebagai pembanding digunakan metode Particle Swarm Optimization sesuai algoritma pada [21] diperoleh hasil

$$
\{\alpha=0.072804, \beta=0.05006\}
$$

dengan error yang dihasilkan 3.6463e - 6. Tampak bahwa kedua metode memberikan hasil yang cukup signifikan serupa dengan tingkat error yang sangat kecil.

Nilai $R_{0}$ berdasarkan persamaan (3) dan dengan menggunakan nilai parameter (6) didapat

$$
R_{0}=1.462577
$$

Nilai $R_{0}$ ini merupakan nilai $R_{0}$ dari model untuk seluruh data pengamatan. Untuk mendapatkan nilai $R_{0}$ harian dilakukan dengan langkah berikut: Untuk $j=t_{s}, t_{s+1}, \ldots, t_{n}$ dengan $s$ adalah hari mulai pengamatan $R_{0}$ dan $n$ adalah banyak data

1. Tentukan solusi dari model (2), $\phi(t)$ untuk $t \in\left[t_{0}, t_{s}\right]$

2. Tentukan residu $r(\alpha, \beta)$ dengan data $d \in\left[d_{1}, d_{s}\right]$

3. Tentukan parameter dengan menggunakan metode kuadrat terkecil berdasarkan persamaan (6).

Jika dipilih $s=10$ dan digunakan data pada Tabel 2, diperoleh data $R_{0}$ harian yang disajikan pada Tabel 3 .

Tabel 3. Data $R_{0}$ harian model SIR yang dihitung mulai dari H+10 berdasarkan Tabel 2

\begin{tabular}{lllllllc}
\hline $\mathrm{H}$ & \multicolumn{1}{c}{$R_{0}$} & $\mathrm{H}$ & $R_{0}$ & $\mathrm{H}$ & \multicolumn{1}{c}{$R_{0}$} & $\mathrm{H}$ & $R_{0}$ \\
\hline 0 & 2.679486 & 12 & 2.263844 & 24 & 1.79883 & 36 & 1.661312 \\
\hline 1 & 2.48301 & 13 & 2.094803 & 25 & 1.805803 & 37 & 1.659376 \\
\hline 2 & 2.842998 & 14 & 2.161605 & 26 & 1.817231 & 38 & 1.676578 \\
\hline 3 & 3.485591 & 15 & 2.094834 & 27 & 1.77175 & 39 & 1.639506 \\
\hline 4 & 2.30247 & 16 & 2.105596 & 28 & 1.798502 & 40 & 1.671237 \\
\hline 5 & 2.668348 & 17 & 2.068033 & 29 & 1.797459 & 41 & 1.624714 \\
\hline 6 & 2.503546 & 18 & 2.032532 & 30 & 1.888254 & 42 & 1.582414 \\
\hline 7 & 2.4023 & 19 & 2.019627 & 31 & 1.869461 & 43 & 1.561957 \\
\hline 8 & 2.462863 & 20 & 1.951918 & 32 & 1.88396 & 44 & 1.550853 \\
\hline 9 & 2.445649 & 21 & 1.894367 & 33 & 1.932953 & 45 & 1.535482 \\
\hline 10 & 2.49309 & 22 & 1.820586 & 34 & 1.987038 & 46 & 1.504313 \\
\hline 11 & 2.389339 & 23 & 1.747733 & 35 & 1.768644 & 47 & 1.462577 \\
\hline
\end{tabular}

Fungsi yang digunakan untuk mengestimasi perilaku data $R_{0}$ pada Tabel 3 diberikan oleh Tabel 4.

Tabel 4. Fungsi estimasi untuk estimasi data $\boldsymbol{R}_{0}$ wilayah Pekanbaru

\begin{tabular}{lll}
\hline No & Fungsi & Bentuk \\
\hline 1 & Polinomial & $P_{n}(x)=a_{0}+a_{1} x+a_{2} x^{2}+\cdots+a_{n} x^{n}, a_{n} \neq 0$ \\
\hline 2 & Trigonometri & $T(x)=a_{0} \sin \left(a_{1} x\right)+a_{2} \cos \left(a_{3} x\right)+a_{4}$ \\
\hline 3 & Eksponensial & $E(x)=a_{0} e^{-a_{1} x}+a_{2}$ \\
\hline 4 & Gabungan & $G(x)=\sum_{i=0}^{5} a_{i} x^{i}+b_{0} \sin \left(b_{1} x\right)+b_{2} \cos \left(b_{3} x\right)+c_{0} e^{-c_{1} x}$ \\
\hline
\end{tabular}


Menggunakan metode kuadrat terkecil yang terintegrasi pada Python, diperoleh parameter hasil estimasi dan error masing-masing fungsi terhadap data $R_{0}$ pada Tabel 5.

Tabel 5. Nilai parameter fungsi Tabel 4 dan error kuadrat terkecil terhadap data $R_{0}$

\begin{tabular}{|c|c|c|}
\hline Fungsi & Parameter & Nilai error \\
\hline Polinomial & $\begin{array}{l}a_{0}=2.69348321 e+00 \\
a_{1}=1.97529194 e+01 \\
a_{2}=-2.02277574 e+03 \\
a_{3}=4.05688432 e+04 \\
a_{4}=-3.22478456 e+05 \\
a_{5}=8.98976483 e+05\end{array}$ & 1.007903961677366 \\
\hline Trigonometri & $\begin{array}{l}a_{0}=1.18029693 e+00 \\
a_{1}=-1.27210711 e+01 \\
a_{2}=1.11669179 e+00 \\
a_{3}=9.05579944 e-04 \\
a_{4}=1.66229425 e+00\end{array}$ & 1.3143531480768593 \\
\hline Eksponensial & $\begin{array}{l}a_{0}=1.50627997 \\
a_{1}=15.69422395 \\
a_{2}=1.36287867\end{array}$ & 1.2334090219670284 \\
\hline Gabungan & $\begin{array}{l}a_{0}=-4.10881667 e-01 \\
a_{1}=8.64363506 e+00 \\
a_{2}=-1.86208073 e+03 \\
a_{3}=4.05981546 e+04 \\
a_{4}=-3.24131081 e+05 \\
a_{5}=9.00704117 e+05 \\
b_{0}=-3.9502067 \\
b_{1}=-2.79587634 \\
b_{2}=3.05462889 \\
b_{3}=10.27268761 \\
c_{0}=0.0497291 \\
c_{1}=-1.39716988\end{array}$ & 1.0079051976580637 \\
\hline
\end{tabular}

Tabel 5 menunjukkan bahwa fungsi polinomial merupakan fungsi terbaik dalam menghampiri data $R_{0}$ harian. Nilai fungsi ini juga lebih baik dibandingkan nilai dari fungsi gabungan. Perbandingan ketiga fungsi serta fungsi gabungan dengan data pada Tabel 3 ditampilkan pada Gambar 3 dan Gambar 4. Terlihat ketiga fungsi hampiran cukup dekat dengan sebaran data meskipun fungsi polinomial merupakan fungsi yang memberikan hampiran terbaik.

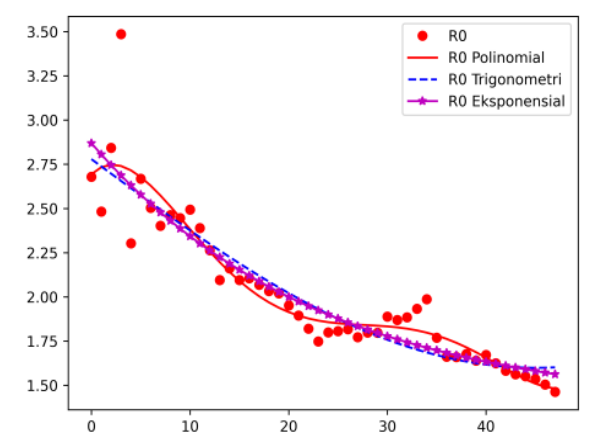

Gambar 3. Perbandingan kurva dari data $\boldsymbol{R}_{\mathbf{0}}$ harian wilayah pekanbaru dengan tiga pertama fungsi estimasi pada Tabel 3.

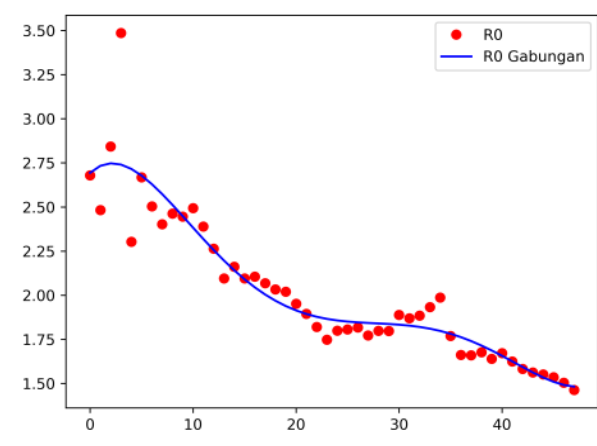

Gambar 4. Perbandingan kurva data $\boldsymbol{R}_{0}$ harian wilayah pekanbaru dengan kurva fungsi gabungan.

\section{c. Desain Kontrol Optimum}

Nilai kontrol $\mu$ pada persamaan (2) merupakan indeks kesuksesan tindakan vaksinasi dalam mencegah penularan infeksi dari populasi sakit pada populasi sehat. Nilai ini berada pada domain $\mathrm{U}=\left\{\mu(t) \mid 0 \leq \mu \leq \mu_{\max }, t \geq 0\right\}$ dengan $\mu_{\max }$ adalah efektivitas maksimum dari vaksinasi yang diberikan. 
Pada laporan [22], terdapat 25 orang dari 1.620 orang yang diberikan vaksinasi yang terinfeksi Covid-19. Hal ini dapat diambil nilai bahwa $\mu_{\max }=\frac{1620-25}{1.620}=0.98$.

Perhatikan kembali persamaan (2). Diberikan performa indeks yang menyatakan biaya yang digunakan untuk mengurangi peningkatan jumlah populasi terinfeksi dan menjaga ketahanan populasi sehat melalui vaksinasi dengan persamaan

$$
J(s, i)=\frac{1}{2} \int_{t_{0}}^{t_{f}} q_{1} s^{2}+q_{2} i^{2}+r u^{2} d t
$$

dengan $q_{1}, q_{2}, r$ menyatakan bobot pengaruh masing-masing variabel terhadap penambahan performa indeks. Masalah kontrol optimum adalah masalah meminimumkan persamaan (10) dengan kendala persamaan (2) yang dapat diselesaikan menggunakan Prinsip Minimum Pontryagin (PMP). Dengan menggunakan metode yang sama pada [23], kontrol optimum didesain dengan menggunakan beberapa langkah berikut:

1. Mendefinisikan fungsi Hamiltonian, yang mengubah masalah optimisasi berkendala menjadi optimisasi tanpa kendala dengan menggunakan pengali Lagrange, yang diberikan oleh

$$
H=\frac{1}{2}\left(q_{1} s^{2}+q_{2} i^{2}+r u^{2}\right)+\lambda_{s}(-\alpha(1-\mu) s i)+\lambda_{i}(\alpha(1-\mu) s i-\beta i)
$$

2. Menentukan nilai kontrol $\mu$ yang meminimumkan fungsi Hamilton, yaitu menentukan $\mu$ yang merupakan titik kritis fungsi Hamilton yang memenuhi $\frac{\partial H}{\partial \mu}=0$ sehingga diperoleh

$$
u=r^{-1}\left(\lambda_{i}-\lambda_{s}\right) \alpha s i
$$

3. Menentukan nilai kontrol $\mu$ yang sesuai untuk solusi berdasarkan himpunan nilai $\mu$. Nilai $\mu$ pada persamaan (12) terbatas di atas oleh $\mu_{\max }$ sehingga

$$
u^{*}= \begin{cases}\mu_{\max } & , \quad \mu \geq \mu_{\max } \\ \mu & , \quad 0 \leq \mu<\mu_{\max } \\ 0 & , \quad \mu<0\end{cases}
$$

Persamaan (13) selanjutnya dapat dinyatakan dengan

$$
u^{*}=\max \left\{0, \min \left\{\mu, \mu_{\max }\right\}\right\}
$$

4. Menentukan fungsi costate untuk masing-masing pengali Lagrange yang berdasarkan PMP, persamaan costate diberikan oleh $-\frac{d \lambda_{s}}{d t}=\frac{\partial H}{\partial s}$ dan $-\frac{d \lambda_{i}}{d t}=\frac{\partial H}{\partial i}$ sehingga didapatkan dua persamaan diferensial

$$
\left\{\begin{array}{l}
\frac{d s}{d t}=-q_{1} s+\left(\lambda_{s}-\lambda_{i}\right) \alpha(1-\mu) i \\
\frac{d i}{d t}=-q_{2} i+\left(\lambda_{s}-\lambda_{i}\right) \alpha(1-\mu) s+\lambda_{i} \beta
\end{array}\right.
$$

dengan nilai batas $s\left(t_{f}\right)=0$ dan $i\left(t_{f}\right)=0$.

Selanjutnya, dengan menggunakan nilai parameter pada persamaan (7), perilaku sistem (2) disimulasikan dengan beberapa kondisi; yaitu tanpa kontrol, vaksinasi dengan efektivitas maksimum, vaksinasi dengan kontrol optimum dan vaksinasi dengan kontrol optimum dengan nilai $\mu_{\text {max }}$ yang berbedabeda. Hasil perbandingan antara model tanpa kontrol, kontrol maksimum, dan kontrol optimum masingmasing ditampilkan pada Gambar 5 dan Gambar 6. 


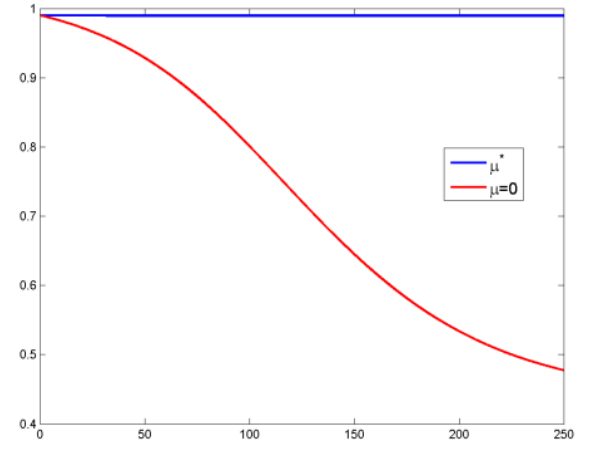

Gambar 5. Perbandingan populasi sehat yang dikontrol dan tanpa kontrol

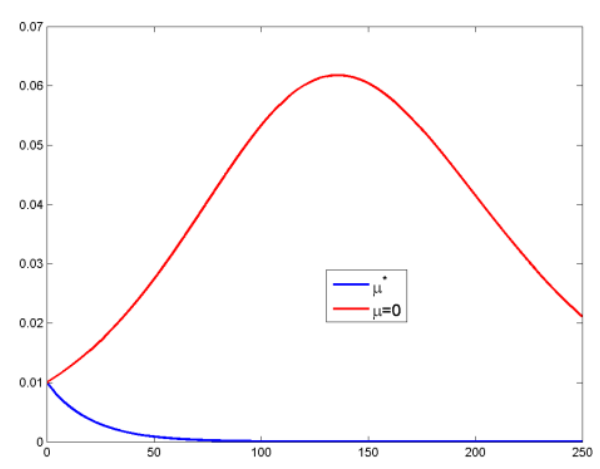

Gambar 6. Perbandingan populasi terinfeksi yang dikontrol dan tanpa kontrol.

Dinamika jumlah populasi yang dikontrol dan tanpa kontrol tampak berbeda secara signifikan. Jumlah populasi sehat tanpa kontrol menurun drastis yang dibarengi dengan kenaikan jumlah populasi terinfeksi. Namun, dengan pemberian kontrol vaksinasi, jumlah populasi terinfeksi langsung turun secara eksponensial sehingga jumlah populasi sehat masih tinggi. Nilai efektivitas kontrol vaksinasi adalah $\mu_{\max }=1$ dimana seluruh populasi sehat yang divaksinasi tidak akan tertular penyakit. Nilai ini sangat dekat dengan nilai efektivitas berdasarkan data $\mu_{\max }=0.98$ yang digunakan sehingga keduanya sangat efektif untuk menekan pertumbuhan populasi terinfeksi. Hal ini dapat dilihat pada Gambar 7 dan Gambar 8.

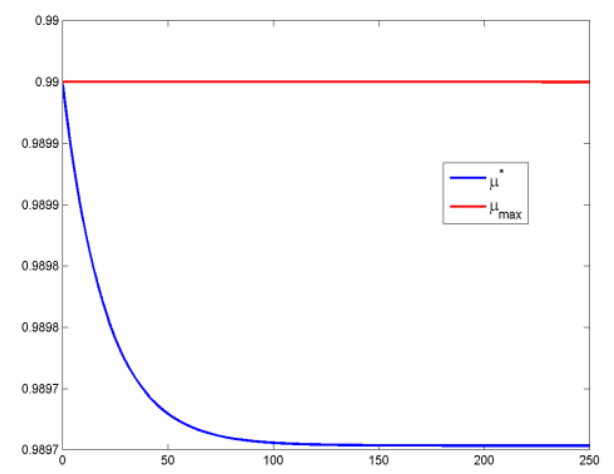

Gambar 7. Perbandingan populasi sehat yang dikontrol maksimum dan kontrol optimum

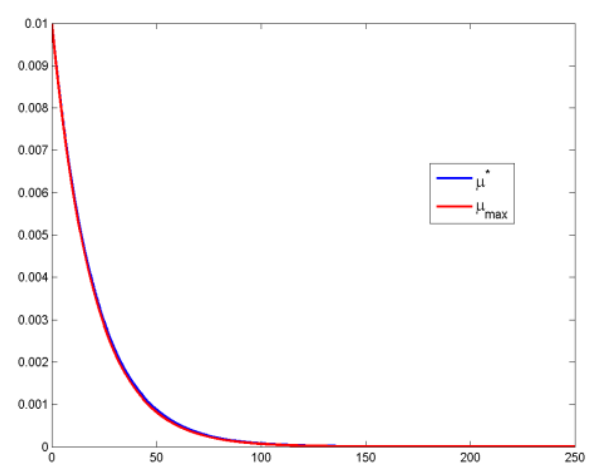

Gambar 8. Perbandingan populasi terinfeksi yang dikontrol maksimum dan kontrol optimum

Efektivitas vaksinasi pada simulasi sebelumnya sangat berpengaruh terhadap kemampuan vaksinasi dalam menekan pertumbuhan populasi terinfeksi. Misalkan dipilih tingkat efektivitas $\mu_{\max }=$ $0.98,0.65,0.25$, pengaruh tingkat efektivitas maksimum terhadap dinamika populasi sehat dan terinfeksi ditampilkan pada Gambar 9 dan Gambar 10.

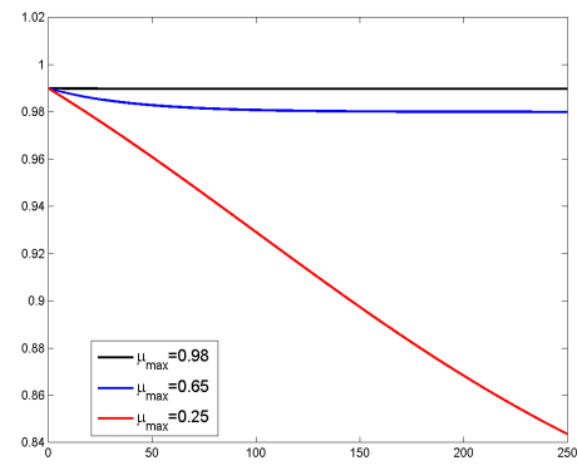

Gambar 9. Perbandingan populasi sehat yang dikontrol dengan nilai $\mu_{\max }$ bervariasi

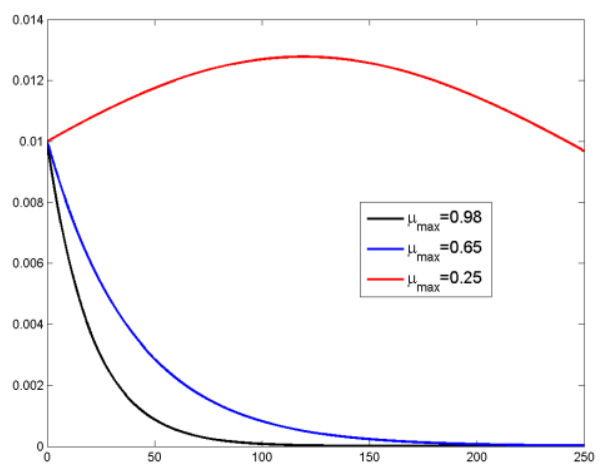

Gambar 10. Perbandingan populasi terinfeksi yang dikontrol dengan nilai $\mu_{\text {max }}$ bervariasi 
Tampak pada Gambar 9 bahwa tingkat efektivitas vaksinasi sebanding dengan perkembangan jumlah populasi terinfeksi dan berbanding terbalik dengan perkembangan jumlah populasi sehat. Semakin tinggi efektivitas vaksinasi, jumlah populasi terinfeksi dapat ditekan serendah mungkin sehingga populasi sehat tetap terjaga. Pada Gambar 10, tingkat efektivitas vaksinasi yang rendah membuat jumlah populasi terinfeksi sempat mengalami kenaikan sebelum kemudian turun, yang berbeda dengan tingkat efektivitas tinggi yang mampu membawa jumlah populasi teinfeksi turun secara eksponensial. Pada $t \approx 140$ terdapat titik maksimum jumlah populasi terinfeksi dengan efektivitas vaksinasi rendah. Terakhir, biaya persamaan (10) dan jumlah populasi terinfeksi maksimum untuk masing-masing $\mu_{\max }$ disajikan pada Tabel 6.

Tabel 6. Nilai biaya dan populasi terinfeksi maksimum untuk masing-masing $\boldsymbol{\mu}_{\max }$

\begin{tabular}{ccc}
\hline $\boldsymbol{\mu}_{\max }$ & Biaya & $\boldsymbol{i}_{\max }$ \\
\hline 0.98 & 291,9 & 0.0100 \\
\hline 0.65 & 295,4 & 0.0100 \\
\hline 0.25 & 523,4 & 0.0128 \\
\hline
\end{tabular}

Pada Tabel 6 tampak bahwa populasi maksimum untuk $\mu_{\max }=0.98$ dan $\mu_{\max }=0.65$ bernilai sama dikarenakan jumlah populasi terinfeksi turun secara eksponensial dari nilai awal dan tidak pernah mengalami kenaikan sedangkan pada $\mu_{\max }=0.25$ populasi masih mengalami kenaikan hingga ke titik tertinggi $i_{\max }=0.0128$ lalu kemudian turun menuju nol.

\section{KESIMPULAN}

Pada artikel ini telah dibahas tentang penyebaran Covid-19 menggunakan model SIR dengan diberikan vaksinasi. Kontrol vaksinasi diturunkan dengan menggunakan kontrol optimum berdasarkan Prinsip Minimum Pontryagin. Data simulasi merupakan data kasus harian pada bulan September - Oktober 2020 di wilayah Pekanbaru dan estimasi parameter dilakukan dengan menggunakan metode kuadrat terkecil. Hasil simulasi terkait bilangan reproduksi dasar menunjukkan bahwa populasi terinfeksi pada rentang bulan ini masih akan bertambah dikarenakan $R_{0}>1$ namun laju penambahan akan berkurang dikarenakan kurva $R_{0}$ terus menurun. Berdasarkan nilai $R_{0}$ yang dihitung secara harian, fungsi polinomial dan eksponensial memberikan hampiran yang baik dibandingkan fungsi trigonometri. Selanjutnya, adanya vaksinasi pada model sangat berperan dalam menekan pertumbuhan populasi terinfeksi. Telah ditunjukkan juga bahwasanya semakin tinggi efektivitas vaksinasi maka semakin efektif vaksinasi dalam menekan laju pertumbuhan populasi terinfeksi sehingga populasi sehat dapat terjaga tetap tinggi.

\section{DAFTAR PUSTAKA}

[1] Y. Li $d k k$., "Mathematical Modeling and Epidemic Prediction of COVID-19 and Its Significance to Epidemic Prevention and Control Measures," Ann. Infect. Dis. Epidemiol., vol. 5, no. 1, hlm. 1-9, 2020.

[2] R. Nuraini, "Kasus Covid-19 Pertama, Masyarakat Jangan Panik," 2020. https://indonesia.go.id/narasi/indonesia-dalamangka/ekonomi/kasus-covid-19-pertama-masyarakat-jangan-panik (diakses Jul 15, 2020).

[3] K. P. C.-19 dan Pemulihan Ekonomi Nasional, "Data Sebaran Covid19 Indonesia," 2020. https://covid19.go.id/ (diakses Nov 26, 2020).

[4] S. Ahmetolan, A. H. Bilge, A. Demirci, A. Peker-Dobie, dan O. Ergonul, "What Can We Estimate From Fatality and Infectious Case Data Using the Susceptible-Infected-Removed (SIR) Model? A Case Study of Covid-19 Pandemic," Front. Med., vol. 7, hlm. 556366, Sep 2020, doi: 10.3389/fmed.2020.556366.

[5] N. Wang, Y. Fu, H. Zhang, dan H. Shi, "An evaluation of mathematical models for the outbreak of COVID-19," Precis. Clin. Med., vol. 3, no. 2, hlm. 85-93, Jun 2020, doi: 10.1093/pcmedi/pbaa016.

[6] B. Malavika, S. Marimuthu, M. Joy, A. Nadaraj, E. S. Asirvatham, dan L. Jeyaseelan, "Forecasting COVID-19 epidemic in India and high incidence states using SIR and logistic growth models," Clin. Epidemiol. Glob. Health, vol. 2021, no. 9, hlm. 26-33, Jan 2021, doi: 10.1016/j.cegh.2020.06.006.

[7] E. B. Postnikov, "Estimation of COVID-19 dynamics 'on a back-of-envelope': Does the simplest SIR model provide quantitative parameters and predictions?," Chaos Solitons Fractals, vol. 135, hlm. 109841, Jun 2020, doi: 10.1016/j.chaos.2020.109841.

[8] W. C. Roda, M. B. Varughese, D. Han, dan M. Y. Li, "Why is it difficult to accurately predict the COVID-19 epidemic?," Infect. Dis. Model., vol. 5, hlm. 271-281, 2020, doi: 10.1016/j.idm.2020.03.001.

[9] I. Rahimi, F. Chen, dan A. H. Gandomi, "A review on COVID-19 forecasting models," Neural Comput. Appl., Feb 2021, doi: 10.1007/s00521-020-05626-8. 
[10] J. Arino dan S. Portet, "A simple model for COVID-19," Infect. Dis. Model., vol. 5, hlm. 309-315, 2020, doi: 10.1016/j.idm.2020.04.002.

[11] A. Aleta dan Y. Moreno, "Evaluation of the potential incidence of COVID-19 and effectiveness of containment measures in Spain: a data-driven approach," BMC Med., vol. 18, no. 157, hlm. 1-12, 2020, doi: 10.1186/s12916-020-01619-5.

[12] W. Lyra, J.-D. do Nascimento Jr., J. Belkhiria, L. de Almeida, P. P. M. Chrispim, dan I. de Andrade, “COVID-19 pandemics modeling with modified determinist SEIR, social distancing, and age stratification. The effect of vertical confinement and release in Brazil," PLOS ONE, vol. 15, no. 9, hlm. 1-17, 2020, doi: 10.1371/journal.pone.0237627.

[13] G. Giordano $d k k$., "Modelling the COVID-19 epidemic and implementation of population-wide interventions in Italy," Nat. Med., vol. 26, no. 6, hlm. 855-860, Jun 2020, doi: 10.1038/s41591-020-0883-7.

[14] S. He, Y. Peng, dan K. Sun, "SEIR modeling of the COVID-19 and its dynamics," Nonlinear Dyn., vol. 101, no. 3, hlm. 1667-1680, Agu 2020, doi: 10.1007/s11071-020-05743-y.

[15] S. O. Alam, "Kemenkes Tegaskan Pasien Corona yang Sembuh Tidak Bisa Menular Lagi," 2020. https://health.detik.com/berita-detikhealth/d-4982214/kemenkes-tegaskan-pasien-corona-yang-sembuh-tidak-bisa-menularlagi?tag_from=wpm_nhl_10 (diakses Jul 14, 2020).

[16] L. Zhang dkk., "Optimal parameterization of COVID-19 epidemic models," Atmospheric Ocean. Sci. Lett., vol. 14, no. 4, hlm. 100024, Jul 2021, doi: 10.1016/j.aosl.2020.100024.

[17] T. E. Simos, C. Tsitouras, V. N. Kovalnogov, R. V. Fedorov, dan D. A. Generalov, "Real-Time Estimation of R0 for COVID-19 Spread," Mathematics, vol. 9, no. 6, hlm. 664, Mar 2021, doi: 10.3390/math9060664.

[18] W. Zhu dan S. Shen, "An improved SIR model describing the epidemic dynamics of the COVID-19 in China," Results Phys., vol. 25, hlm. 104289, Jun 2021, doi: 10.1016/j.rinp.2021.104289.

[19] G. Chowell, "Fitting dynamic models to epidemic outbreaks with quantified uncertainty: A primer for parameter uncertainty, identifiability, and forecasts," Infect. Dis. Model., vol. 2, no. 3, hlm. 379-398, Agu 2017, doi: 10.1016/j.idm.2017.08.001.

[20] Badan Pusat Statistik Kota Pekanbaru, "Kota Pekanbaru Dalam Angka $2020, " 2020$. https://pekanbarukota.bps.go.id/publication/2020/04/27/2e4544f6ddb701728d7e8a36/kota-pekanbaru-dalam-angka2020.html (diakses Agu 30, 2020).

[21] S. Putra, K. Mu'tamar, dan Zulkarnain, "Estimation of Parameters in the SIR Epidemic Model Using Particle Swarm Optimization," Am. J. Math. Comput. Model., vol. 4, no. 4, hlm. 83, 2019, doi: 10.11648/j.ajmcm.20190404.11.

[22] R. Franedya, "25 Relawan Uji Vaksin Corona Sinovac Bandung Positif Covid-19,” 2021. https://www.cnbcindonesia.com/tech/20210118143205-37-216856/25-relawan-uji-vaksin-corona-sinovac-bandung-positifcovid-19 (diakses Jan 25, 2021).

[23] K. Mu'tamar, D. Rahmalia, dan S. Sutimin, "Vaksinasi dan Treatment pada Predator-Prey dengan Dua Jenis Pemangsa yang Salah Satunya Terinfeksi,” EKSAKTA J. Ilmu-Ilmu MIPA, vol. 19, no. 2, hlm. 128-142, 2019. 
